\title{
PERCEPTION OF UNDERGRADUATES' ABOUT COMPUTER AND INTERNET ETHICS IN PAKISTAN
}

\author{
M. Jamil ${ }^{1,}$ and J. H. Shah ${ }^{2}$ \\ 1DEPARTMENT OF EDUCATION, BAHAUDDIN ZAKARIYA UNIVERSITY, MULTAN, PAKISTAN \\ 2DEPARTMENT OF EdUCATION, MOHI-UD-DIN ISLAMIC UNIVERSITY, AZAD JAMMU AND KASHMIR, PAKISTAN \\ E-mail addresses: 1 mubashrahj@gmail.com, ${ }^{2}$ jamilshah@email.com
}

\begin{abstract}
Computer and internet has brought innovative changes in education all over the world. In the universities of Pakistan, computer and IT related courses have recently been included as compulsory subjects in all disciplines at undergraduate level. Therefore, it was important to know the perceptual understanding and awareness of university teachers and undergraduate students about the ethical use of computer and internet through a survey. A total of 378 teachers and 643 students from four different universities participated in the study and the results were interpreted on the bases of their demographic information. Overall, the results were not very highly appreciated regarding the awareness about computer and IT ethics. But teachers from private sector universities and male students from both private and public sector universities were found perceptually more positive than to others. It was recommended that computer ethics awareness training is needed for all the stakeholders of all universities.
\end{abstract}

Keywords: computer ethics, undergraduate perceptions, IT ethics, IT ethics awareness, cyber ethics

\section{INTRODUCTION}

Ethics is the question of right and wrong in human conduct $[4,16]$ and computer ethics are the ethics regarding the use of computer and IT $[10,21]$. In the same context [30] explained that 'computer ethics deals with how to make moral decisions while using technology whether in workplace or in society in general'. Advancement in information and communication technologies (ICTs) has empowered the users [23] and their frequent accessibility and utilization increased the chance of unethical use of these resources. These unethical uses may harm individuals or even societies. These activities may include hacking, spam, denial of service attacks, identity theft, unauthorized duplication of software, digital plagiarism and improper uses of digital resources $[1,3,5,18,25]$.

Iskandarani, El-Refae and El-Etter[12] critically explained that internet - in the very beginning - has two simple rules i.e., anyone could say anything and nothing was official. This was the best method of finding solid solutions for technical problems. But it was miss-interpreted and now there are networks, forums and websites where anarchy reigns. These were categorized and explained by [24, 27] which presented architecture for teaching computer ethics online. They quoted from Forester and Morrison the following seven categories of unethical uses or abuses of ICTs: computer crime and computer security, software theft and intellectual property rights, computer hacking and creating of viruses; computer and information systems failure; invasion of privacy; the social implications of artificial intelligence and expert systems; and workplace computerization. To handle these problems, authors suggested for identifying the meaning of computer and IT ethics by the users; discuss ethical problems by considering each other's point of view; then explain the ethical problems in terms of real life problems; create a situation for them and then analyze how they would be able to provide the solution of the problem.

Data processing and sharing of information are basic characteristics of computer and information technologies [7] which are also the roots of unethical utilization of the same resources. Regarding computer or IT ethics' applications in education different authors expressed and analyzed differently. For example:

Article [28] expressed that there are misconceptions about copyright laws and ethical issues regarding the 
use of computer among students, therefore, it would be effectiveness to include this in curriculum; it was confirmed by [25] and added that computer and IT are widely being used in educational settings, it seems reasonable and necessary to include computer and IT ethics in curriculum [19]; related to these two papers, it was studied the differences between plagiarism acts from printed sources and internet sources[2]. They revealed that the students were unable to distinguish printed and internet sources because they perceived the information on the internet was free for use. In this regard they suggested treating potential information sources separately in research, in order to gain a full understanding of the phenomenon. They highlighted:

a) Perfect students' insights regarding the ethical use of online information;

b) teach them how to cite internet sources properly and

c) explain the importance of protecting intellectual property rights.

By doing so, universities can reduce the extent of plagiarism, and particularly internet plagiarism, committed by students; students from different disciplines are using computers as research tools and to communicate with friends and colleagues[3]; therefore, it is very important to educate them meaningfully to use these resources effectively and properly; students' ethical attitudes were surveyed towards computer use, it was found that the median rank for all activities is in the range of somewhat unethical to very unethical[18]. Personal use of software or downloads was judged more as being just somewhat unethical as was hacking into a computer system for reasons of intellectual curiosity [17]. Malicious activity was judged primarily in the unethical to very unethical range [6, 22]. Accessing other peoples records, changing code for personal gain and causing reduced response time for a company that was believed to exploit its workers and was unfriendly to the environment was viewed no more negatively than the same activity performed without malicious intent [30]. On the other hand, teaching of computer ethics to students will raise the awareness and understanding among them which will ultimately affect the effective utilization of computer and IT tools[13]; it was highlighted and focused by [5] that plagiarism, copyright and software theft, hacking, improper use of computer resources, and harassment are the common practices among teachers and students from higher educational institutions; in the same directions [29] found in their studies that students of elementary level believe that software piracy is a legal act.

According to [11], 'ICT received a significant amount of attention from ethicists as well as sociologists, anthropologists, and scholars in law, education, and communication studies. Recently, computer ethics broadened to ethics of information technology and information ethics, a more general field that includes computer ethics, media ethics, library ethics, and bioinformation ethics'. Computer and IT ethics studies have been conducted in developed countries; however under developed countries are in the process of identifying the importance and role and establishing the culture about the ethical use of computer and IT. Pakistan is one of the under developed countries where Government is spending a significant amount of resources to improve the quality of education at all levels but especially at higher educational institutions. There have been many significant developments and changes in teaching and learning techniques and resources. It was surveyed by [15] that teachers are preparing lectures and notes (i.e., by downloading materials from internet), constructing question papers online, emailing assignments online, online marking of assignments and answer sheets, declaring students results online, using email to send and receive feedback to/from students and also providing CDs and web links related to course content to students in the classrooms. Authors of the same study further explained that basic IT resources i.e., computer, printer and internet are provided to all teachers in their offices. Each department / or discipline has their own computer lab for students. Moreover, trainings are being provided to teachers and students to utilize these resources effectively by the Higher Education Commission, Pakistan. It was observed and experienced by the authors of the current study that recently, all public and private sector universities have included compulsory courses related to the training of computer and internet in all the disciplines of undergraduate studies. This increased use of computer and internet across the curriculum compels our teachers and students to be knowledgeable about computer and IT ethics.

Therefore, this paper will focus on the particular issues associated with the ethical use of computer and information technologies (C\&IT) by the undergraduate teachers and students of the sampled universities. Many of the ethical issues related to the use of C\&IT raised in the paper were applicable to the 
teaching - learning activities that require sound knowledge and professional understanding - in the absence of which - may have negative impact on learning. By addressing computer ethics within the context of teaching profession, not only expose the level of awareness among the teachers and students but will also bring attention of higher authorities to train teachers and students in this particular direction as well, so that the C\&IT resources provided by the government could be utilized properly and effectively.

\section{RESEARCH QUESTIONS}

Following research questions were formulated for the study:

Q1: whether sampled teachers and undergraduate students have same ethical believes?

Q2: whether sampled teachers in Public and Private Universities have same ethical believes?

Q3: whether undergraduate students in Public and

Private Universities have same ethical believes?

Q4: whether male and female teachers in Public and

Private Universities have same ethical believes?

Q5: whether male and female students in Public and

Private Universities have same ethical believes?

\section{METHODOLOGY}

\subsection{Tool of the Study}

Study was descriptive; therefore, a self-reported questionnaire was designed to collect data from teachers and undergraduate students during the semesters of 2011-12 from two public and two private sector. The research was greatly inspired by the studies of [8], [20] and [26]. Two parts of the questionnaire were designed to solicit responses. Part - I was designed to collect demographic information which included: university and gender (see Fig. 1 - 4). Information regarding the prior knowledge and training of IT and IT ethics were also inquired in this section of the questionnaire. While, Part - II was comprised of 16 statements in which respondents were required to respond for the given statement in terms of Right, Wrong and Neither Right Nor Wrong. All statements were presenting some activities/ conditions related to the ethical use of computer and internet; which helped to portray their awareness about the ethical use of computer or IT.

\subsection{Data Analysis}

The scale was rated from 1 to 3 i.e., 1 = Right, $2=$ Wrong and $3=$ Neither Right Nor Wrong (NRNW). The collected responses were fed in MS Excel 2007 ${ }^{\circ}$ and were analyzed demographically. Statistically, frequencies and percentages were calculated to conclude the results. The Cronbach Alpha test was used to measure the reliability of the items in the tool. Result of the reliability test was 0.73 , and hence was acceptable [9].

\subsection{Sampling and Respondents}

All the four universities were delimited on the bases of convenience based sampling. Regarding the private sector universities, only those were included in the study, which were recognized as degree awarding institution by Higher Education Commission Pakistan. Another delimitation of the study was those undergraduate students who were in semesters 3 and 4 during January - December 2012; which constituted the population of this study. These semesters were delimited because basic computer and internet training courses were compulsory for all students in these two semesters. The questionnaires were distributed among the students within their classrooms and teachers were traced within their offices to ensure the maximum feedback, which resulted for 643 students and 378 teachers. Therefore, 643 students and 378 teachers were considered to be the sample of the study.

Figures 1 and 2 showed the overall presentation of sampled teachers and students from both public sector and private sector universities. It was interpreted from the data that both teachers and students from public sector universities were greater in terms of percentages.

Figure 3 exhibited the gender wise distribution of the sampled teachers. It was portrayed that overall male teachers' responses were greater than that of female teachers. Same situation was found in case of private sector universities teachers.

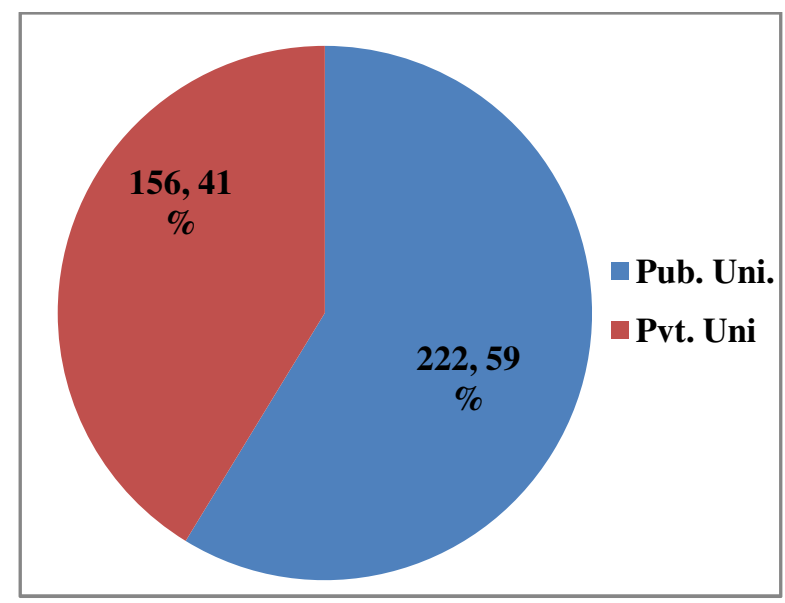

Figure 1: Overall Sampled Teachers 


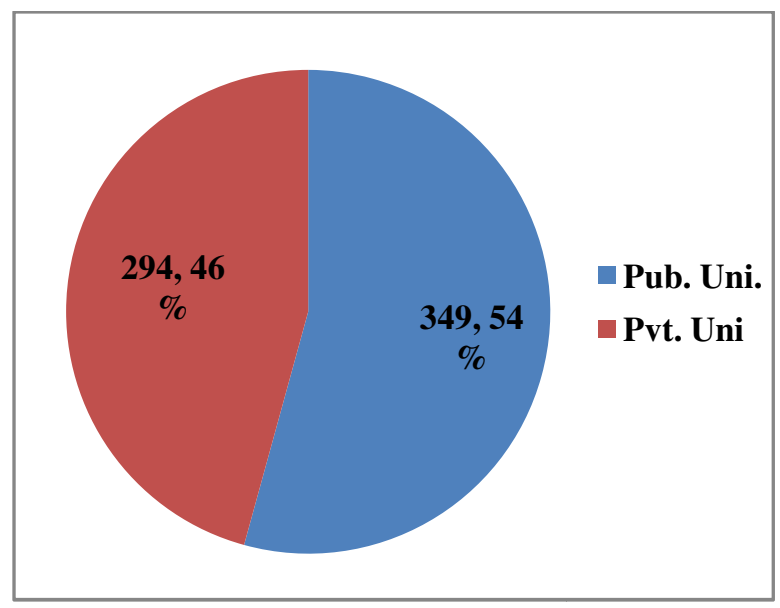

Figure 2: Sampled Students

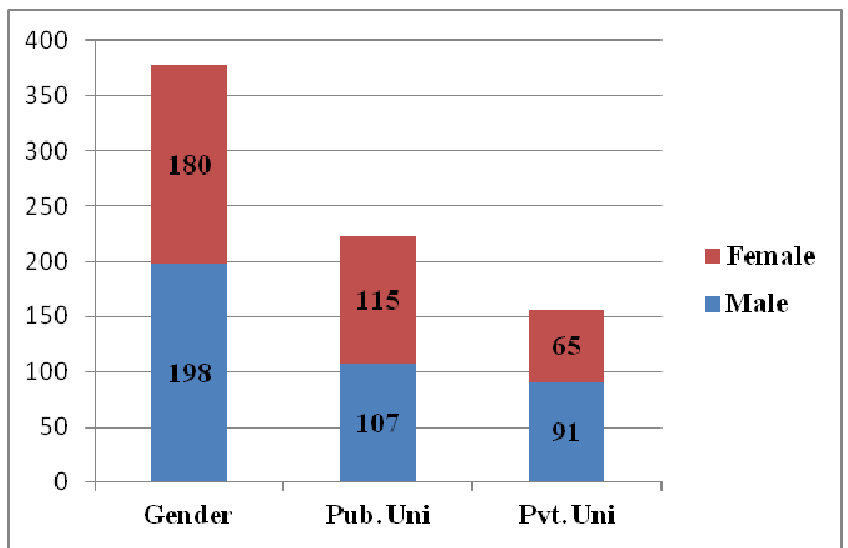

Figure 3: Gender wise distribution of sampled Teachers

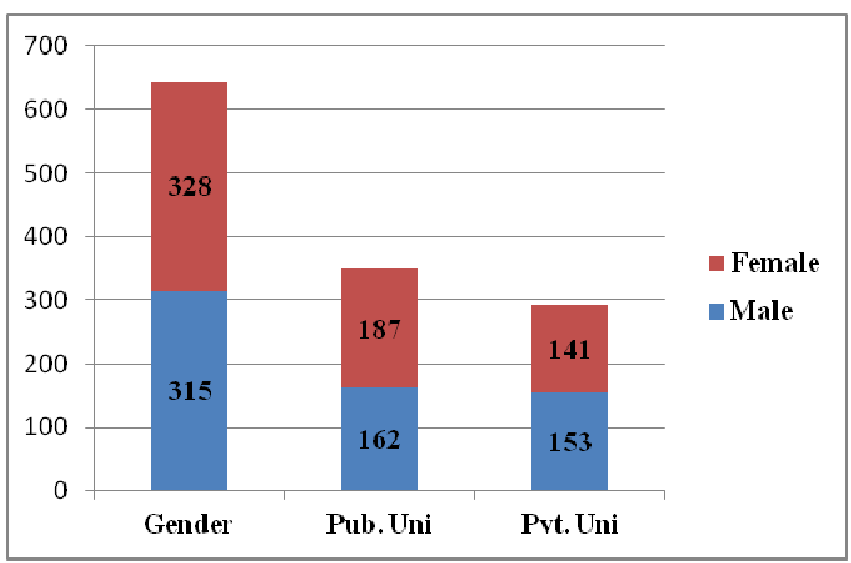

Figure 4: Gender wise distribution of sampled Students
Figure 4 demonstrated the gender wise distribution of the sampled students. It was portrayed that overall female students' participation was greater than that of male students. Same situation was found in case of public sector universities.

Moreover, it was found that total 53\% teachers admitted that they have no IT training certificate. On the other hand 56\% teachers and 58\% students disclosed that they have no prior knowledge about IT and computer ethics.

\section{RESULTS}

Q1: whether sampled teachers and undergraduate students in Public and Private Sector Universities have same ethical believes?

Form Table 1 it was depicted that overall sampled teachers $(99 \%, n=375)$ and students $(75 \%, n=481)$ strongly believe that knowledge about ethical use of computer and IT is important for all. Regarding statement 2, 66\% $(n=250)$ teachers believe that downloading music or movies from internet free of cost is NRNW while $41 \%(n=229)$ students believe this is not an ethical issue; $76 \%(n=286)$ of the teachers and $66 \%(n=304)$ of the students expressed that buying a paper online and submitting it as your own is an unethical activity. Major differences among overall sampled teachers and students were found in statements 6, 10 and 13 . In statement 6, 55\% $(n=207)$ teachers expressed that it is NRNW to quote every author during lecture while 66\% $(n=422)$ students understand that it is wrong to explain a topic without quoting the real author during presentation. Similarly, 90\% $(n=342)$ teachers and 52\% $(n=332)$ expressed that it is important to quote authors even copying and pasting a single sentence from online resources. Overall 65\% $(n=413)$ students said it is true that cheap access of computer and IT tools is one of the reasons for unethical utilization of computer and IT resources students but $72 \%(n=271)$ teachers do not believe on this.

Table 1: Responses of Overall Sampled Teachers and Students - Part II of the Questionnaire

\begin{tabular}{lllllll}
\hline \multirow{2}{*}{$\begin{array}{l}\text { Sr. } \\
\text { No. }\end{array}$} & Statements & \multicolumn{2}{l}{ Overall Teachers $(\mathrm{n}=378)$} & \multicolumn{3}{l}{ Overall Students (n=643) } \\
\cline { 2 - 7 } & Right & Wrong & NRNW & Right & Wrong & NRNW \\
\hline 2. & $\begin{array}{l}\text { Downloading music or movies from } \\
\text { net is: }\end{array}$ & 34 & 94 & 250 & 261 & 153 \\
$\begin{array}{l}\text { Information about ethical use of } \\
\text { computer and technology is } \\
\text { important: }\end{array}$ & 375 & - & 3 & 481 & 26 & 136 \\
3. & & & & &
\end{tabular}




\begin{tabular}{|c|c|c|c|c|c|c|c|}
\hline \multirow{2}{*}{$\begin{array}{l}\text { Sr. } \\
\text { No. }\end{array}$} & \multirow{2}{*}{ Statements } & \multicolumn{3}{|c|}{ Overall Teachers $(n=378)$} & \multicolumn{3}{|c|}{ Overall Students $(n=643)$} \\
\hline & & Right & Wrong & NRNW & Right & Wrong & NRNW \\
\hline 4. & $\begin{array}{l}\text { Buying a paper online and } \\
\text { submitting it as your own is: } \\
\text { Explaining a topic during }\end{array}$ & 57 & 286 & 35 & 188 & 304 & 151 \\
\hline 6. & $\begin{array}{l}\text { lecture/presentation without } \\
\text { quoting the author is: }\end{array}$ & 51 & 120 & 207 & 99 & 422 & 122 \\
\hline 10. & $\begin{array}{l}\text { Copying and pasting one sentence } \\
\text { from an online source, in your } \\
\text { research work, without } \\
\text { acknowledging the source is: } \\
\text { Downloading diagrams or }\end{array}$ & 23 & 342 & 13 & 119 & 332 & 192 \\
\hline 11. & $\begin{array}{l}\text { illustrations from web sites with } \\
\text { complete reference is: }\end{array}$ & 293 & 63 & 22 & 127 & 288 & 228 \\
\hline 13. & $\begin{array}{l}\text { Economically cheap access of } \\
\text { computer and technology makes it } \\
\text { easier to perform different wrong } \\
\text { activities: }\end{array}$ & 69 & 271 & 38 & 413 & 93 & 137 \\
\hline
\end{tabular}

Q2: whether sampled teachers in Public and Private Sector Universities have same ethical believes?

From Table 2 it was found that $52 \%(n=114)$ teachers from public universities expressed that it is not an unethical issue to share original software for educational purposes while $71 \%(n=110)$ teachers from private universities strictly expressed that this is wrong; $74 \%(n=164)$ public sector $55 \%(n=86)$ private sector teachers expressed that it is NRNW to download music and movies; 54\% $(\mathrm{n}=119)$ public sector while $65 \%(\mathrm{n}=102)$ while private sector teachers were unable to decide whether it is right or wrong to download and use online research tools without quoting the real author; $56 \%(\mathrm{n}=125)$ public sector and $66 \%(n=104)$ private sector teachers believe that it is wrong to including references in bibliography list without quoting them in the main text; and $64 \%(n=143)$ teachers public universities believe that sharing and solve research or subject related problems through on line chatting is ethically right while teachers from private sector universities' responses were unable to decide whether it is right or wrong.

\section{Q3: whether undergraduate students from Public and Private Sector Universities have same ethical believes?}

From Table 3 it was disclosed that $62 \%$ each from public $(n=218)$ and private $(n=182)$ sector university students expressed that it is right to copy original software for education purpose; $70 \%(\mathrm{n}=245)$ public sector and $60 \%(n=177)$ students from private universities believe that it is ethically wrong to explain a topic without quoting the real authors; $60 \%$ $(n=211)$ students of public sector understands that it is ethically wrong to use an online research tool without getting permission is ethically wrong but students from private universities were unable to decide whether it is right or wrong; students from both sides were not clear about statements $11,12,14$ and 16. These results reflect that they have poor knowledge about ethical utilization of computer and IT resources.

\section{Q4: whether male and female teachers in Public and Private Sector Universities have same ethical believes?}

From Table 4 it was explored that $100 \%$ teachers from both public $(\mathrm{n}=107)$ and private $(\mathrm{n}=115)$ universities understands the importance of information regarding ethical use of technological resources in education; 67\% $(n=72)$ male and $80 \%$ $(n=92)$ female teachers of public universities marked on NRNW in the response of the activity to download music or movies available online; $70 \%(n=74)$ male and $76 \%(n=87)$ female believe it is ethically wrong to copy and paste any online essay/research paper or any topic related to their subject and present as it their own; responses of statements 9, 12 and 16 from both male and female teachers responses were not supportive to decide about their awareness; but $91 \%$ $(n=105)$ female teachers expressed that sharing original software with friends is ethically right.

Results of Table 5 showed that $73 \%$ each male $(n=66)$ and female $(n=48)$ teachers' from private universities believe that copying original software for educational 
purpose is ethically right; $58 \%(\mathrm{n}=53)$ male and $51 \%$ $(n=33)$ female teachers responded that it is NRNW to download music or movies file from net; and 100\% $(\mathrm{n}=91)$ male and 65\% $(\mathrm{n}=56)$ female teachers expressed that copying and pasting a single line from a web page is NRNW activity.

Table 2: Responses of Sampled Teachers from Public $(n=222)$ and Private $(n=156)$ Universities

\begin{tabular}{|c|c|c|c|c|c|c|c|}
\hline \multirow{2}{*}{$\begin{array}{l}\text { Sr. } \\
\text { No. }\end{array}$} & \multirow{2}{*}{ Statements } & \multicolumn{3}{|c|}{ Teachers from Public Uni. } & \multicolumn{3}{|c|}{ Teachers from Private Uni. } \\
\hline & & Right & Wrong & NRNW & Right & Wrong & NRNW \\
\hline 1. & $\begin{array}{l}\text { Copying original software for } \\
\text { education purposes is: }\end{array}$ & 114 & 34 & 8 & 39 & 110 & 7 \\
\hline 2. & $\begin{array}{l}\text { Downloading music or movies from } \\
\text { net is: }\end{array}$ & 12 & 46 & 164 & 22 & 48 & 86 \\
\hline 7. & $\begin{array}{l}\text { Downloading and using a research } \\
\text { tool for your own research work } \\
\text { but ignoring the real author is: }\end{array}$ & 24 & 79 & 119 & 20 & 34 & 102 \\
\hline 8. & $\begin{array}{l}\text { Listing web sites that you do not } \\
\text { use to complete a research paper in } \\
\text { the bibliography is: }\end{array}$ & 48 & 125 & 49 & 31 & 104 & 21 \\
\hline 9. & $\begin{array}{l}\text { Copying two lines from a printed } \\
\text { source, in your research work, } \\
\text { without acknowledging the source } \\
\text { is: }\end{array}$ & 47 & 123 & 52 & 36 & 90 & 30 \\
\hline 12. & $\begin{array}{l}\text { Using internet chat rooms to ask } \\
\text { about your subject is: }\end{array}$ & 112 & 36 & 74 & 60 & 35 & 61 \\
\hline 14. & $\begin{array}{l}\text { Unauthorized sharing of original } \\
\text { software with friends is: }\end{array}$ & 143 & 57 & 22 & 94 & 31 & 31 \\
\hline 16. & $\begin{array}{l}\text { Writing a summary based on an } \\
\text { online abstract of a journal article } \\
\text { rather than reading the article } \\
\text { itself: }\end{array}$ & 90 & 56 & 76 & 80 & 34 & 42 \\
\hline
\end{tabular}

Table 3: Responses of Sampled Students from Public $(n=349)$ and Private $(n=294)$ Universities

\begin{tabular}{|c|c|c|c|c|c|c|c|}
\hline \multirow{2}{*}{$\begin{array}{l}\text { Sr. } \\
\text { No. }\end{array}$} & \multirow{2}{*}{ Statements } & \multicolumn{3}{|c|}{ Students from Public Uni. } & \multicolumn{3}{|c|}{ Students from Private Uni. } \\
\hline & & Right & Wrong & NRNW & Right & Wrong & NRNW \\
\hline 1. & $\begin{array}{l}\text { Copying original software for } \\
\text { education purposes is: } \\
\text { Explaining a topic during }\end{array}$ & 218 & 58 & 73 & 182 & 54 & 58 \\
\hline 6. & $\begin{array}{l}\text { lecture/presentation without } \\
\text { quoting the author is: }\end{array}$ & 46 & 245 & 58 & 53 & 177 & 64 \\
\hline 7. & $\begin{array}{l}\text { Downloading and using a research } \\
\text { tool for your own research work } \\
\text { but ignoring copy right acts is: } \\
\text { Downloading diagrams or }\end{array}$ & 48 & 211 & 90 & 72 & 143 & 79 \\
\hline 11. & $\begin{array}{l}\text { illustrations from web sites with } \\
\text { complete reference is: }\end{array}$ & 73 & 164 & 112 & 54 & 124 & 116 \\
\hline 12. & $\begin{array}{l}\text { Using internet chat rooms to ask } \\
\text { about your subject is: }\end{array}$ & 87 & 161 & 101 & 112 & 83 & 99 \\
\hline 14. & $\begin{array}{l}\text { Unauthorized sharing of original } \\
\text { software with friends is: }\end{array}$ & 194 & 83 & 72 & 135 & 71 & 88 \\
\hline 16. & $\begin{array}{l}\text { Writing a summary based on an } \\
\text { online abstract of a journal article } \\
\text { rather than reading the article } \\
\text { itself: }\end{array}$ & 125 & 73 & 118 & 122 & 51 & 85 \\
\hline
\end{tabular}


Table 4: Responses of Male $(n=107)$ and Female $(n=115)$ Teachers from Public Universities

\begin{tabular}{|c|c|c|c|c|c|c|c|}
\hline \multirow{2}{*}{$\begin{array}{l}\text { Sr. } \\
\text { No. }\end{array}$} & \multirow{2}{*}{ Statements } & \multicolumn{3}{|c|}{ Male Teachers } & \multicolumn{3}{|c|}{ Female Teachers } \\
\hline & & Right & Wrong & NRNW & Right & Wrong & NRNW \\
\hline 2. & $\begin{array}{l}\text { Downloading music or movies } \\
\text { from net is: }\end{array}$ & 4 & 31 & 72 & 8 & 15 & 92 \\
\hline 3. & $\begin{array}{l}\text { Information about ethical use of } \\
\text { computer and technology is } \\
\text { important: }\end{array}$ & 107 & - & - & 115 & - & - \\
\hline 5. & $\begin{array}{l}\text { Copying and pasting an essay } \\
\text { from the Internet and } \\
\text { submitting it as your own is: }\end{array}$ & 24 & 74 & 9 & 17 & 87 & 11 \\
\hline 9. & $\begin{array}{l}\text { Copying two lines from a } \\
\text { printed source, in your research } \\
\text { work, without acknowledging } \\
\text { the source is: }\end{array}$ & 26 & 58 & 23 & 21 & 65 & 29 \\
\hline 12. & $\begin{array}{l}\text { Using internet chat rooms to } \\
\text { ask about your subject is: }\end{array}$ & 52 & 18 & 37 & 60 & 18 & 37 \\
\hline 14. & $\begin{array}{l}\text { Unauthorized sharing of } \\
\text { original software with friends } \\
\text { is: }\end{array}$ & 38 & 57 & 12 & 105 & - & 10 \\
\hline 16. & $\begin{array}{l}\text { Writing a summary based on an } \\
\text { online abstract of a journal } \\
\text { article rather than reading the } \\
\text { article itself: }\end{array}$ & 46 & 27 & 34 & 44 & 29 & 42 \\
\hline
\end{tabular}

Table 5: Responses of Male $(n=91)$ and Female $(n=65)$ Teachers from Private Universities

\begin{tabular}{|c|c|c|c|c|c|c|c|}
\hline \multirow{2}{*}{$\begin{array}{l}\text { Sr. } \\
\text { No. }\end{array}$} & \multirow{2}{*}{ statements } & \multicolumn{3}{|c|}{ Male Teachers } & \multicolumn{3}{|c|}{ Female Teachers } \\
\hline & & Right & Wrong & NRNW & Right & Wrong & NRNW \\
\hline 1. & $\begin{array}{l}\text { Copying original software for } \\
\text { education purposes is: }\end{array}$ & 66 & 17 & 8 & 48 & 17 & - \\
\hline 2. & $\begin{array}{l}\text { Downloading music or movies } \\
\text { from net is: }\end{array}$ & 8 & 30 & 53 & 14 & 18 & 33 \\
\hline 4. & $\begin{array}{l}\text { Buying a paper online and } \\
\text { submitting it as your own is: }\end{array}$ & 21 & 62 & 8 & 9 & 50 & 6 \\
\hline 7. & $\begin{array}{l}\text { Downloading and using a } \\
\text { research tool for your own } \\
\text { research work but ignoring } \\
\text { copy right acts is: }\end{array}$ & 17 & 13 & 61 & 3 & 21 & 41 \\
\hline 10. & $\begin{array}{l}\text { Copying and pasting one } \\
\text { sentence from an online source, } \\
\text { in your research work, without } \\
\text { acknowledging the source is: }\end{array}$ & - & - & 91 & 7 & 2 & 56 \\
\hline 13. & $\begin{array}{l}\text { Economically cheap access of } \\
\text { computer and technology } \\
\text { makes it easier to perform } \\
\text { different wrong activities: }\end{array}$ & 29 & 51 & 11 & 2 & 53 & 10 \\
\hline
\end{tabular}

Q5: whether male and female students in Public and Private Sector Universities have same ethical believes?

Table 6 portrayed that $59 \%(\mathrm{n}=95)$ male and $66 \%$ $(n=123)$ female students from public sector universities believed that copying original software for educational purposes is ethically right activity; regarding statement 2 their responses were apparently scattered and were not supportive to make any decision regarding their awareness but majority of them were marked the option NRNW; 54\% ( $\mathrm{n}=96)$ male and $56 \%(n=116)$ female students believe that it is ethically wrong to include the references of websites that were not used to complete a research work or assignment; 59\% ( $n=73)$ male and $60 \%$ $(n=102)$ female expressed that copying text from printed sources without acknowledging the real author is ethically wrong; $50 \%(n=8)$ male students and $61 \%(n=114)$ female students from public universities disclosed that unauthorized sharing of 
original software among the friend is ethically right to them.

Table 7 showed that $68 \%(n=103)$ male and $56 \%$ $(n=79)$ female students from private sector universities were believe in copying original software for educational purposes is ethically right activity; regarding statements 4 and 5 their responses were apparently scattered and were not supportive to make any decision regarding their awareness but majority of them were marked the option Wrong; $51 \%(n=78)$ male students believe that it is ethically wrong to listing irrelevant website references in the assignments or research works while female were indecisive again; $59 \%(n=89)$ male and $55 \%(n=78)$ female students expressed that copying text from printed sources without acknowledging the real author is ethically wrong; each male and female students' responses from private universities were scattered among the ranges, and hence therefore unable to decide about their awareness about statement 15.

\section{CONCLUSIONS}

Results found from the survey were not very highly appreciated because overall sampled teachers and students were not properly educated about computer and IT ethics. Regarding the information about computer and IT training and prior knowledge about computer and IT ethics it was found that majority of the teachers were using IT resources professionally because of their personal interest and have not been properly trained from any institution, while majority of both sampled teachers and students disclosed that they have not been provided proper knowledge or information (i.e., included in their course outline or generally discussed in their classes between or among teachers and students) regarding the use of computer and IT ethics during their previous educational durations.

From the calculated frequencies and percentages it was concluded that there were no significant differences found between the responses of overall sampled teachers and students regarding the ethical use of computer and IT resources except on two situations: one is in which, teachers believe that it is good to quote every author during lecture or presentations but not necessarily important and cheap access of Computer and IT resources is not the only reason of unethical utilization of these resources, while students do not.

Table 6: Responses of Male $(n=162)$ and Female $(n=187)$ Students from Public Universities

\begin{tabular}{|c|c|c|c|c|c|c|c|}
\hline \multirow{2}{*}{$\begin{array}{l}\text { Sr. } \\
\text { No. }\end{array}$} & \multirow{2}{*}{ Statements } & \multicolumn{3}{|c|}{ Male Students } & \multicolumn{3}{|c|}{ Female Students } \\
\hline & & Right & Wrong & NRNW & Right & Wrong & NRNW \\
\hline 1. & $\begin{array}{l}\text { Copying original software for } \\
\text { education purposes is: }\end{array}$ & 95 & 21 & 46 & 123 & 37 & 27 \\
\hline 2. & $\begin{array}{l}\text { Downloading music or movies from } \\
\text { net is: }\end{array}$ & 54 & 47 & 61 & 83 & 55 & 49 \\
\hline 8. & $\begin{array}{l}\text { Listing web sites that you do not } \\
\text { use to complete a research paper in } \\
\text { the bibliography is: }\end{array}$ & 35 & 87 & 40 & 60 & 105 & 22 \\
\hline 9. & $\begin{array}{l}\text { Copying two lines from a printed } \\
\text { source, in your research work, } \\
\text { without acknowledging the source } \\
\text { is: }\end{array}$ & 20 & 96 & 46 & 34 & 116 & 37 \\
\hline 10. & $\begin{array}{l}\text { Copying and pasting one sentence } \\
\text { from an online source, in your } \\
\text { research work, without } \\
\text { acknowledging the source is: }\end{array}$ & 31 & 73 & 58 & 37 & 102 & 48 \\
\hline 14. & $\begin{array}{l}\text { Unauthorized sharing of original } \\
\text { software with friends is: }\end{array}$ & 80 & 37 & 45 & 114 & 46 & 27 \\
\hline 16. & $\begin{array}{l}\text { Writing a summary based on an } \\
\text { online abstract of a journal article } \\
\text { rather than reading the article } \\
\text { itself: }\end{array}$ & 55 & 32 & 54 & 70 & 41 & 64 \\
\hline
\end{tabular}


Table 7: Responses of Male $(n=153)$ and Female $(n=141)$ Students from Private Universities

\begin{tabular}{|c|c|c|c|c|c|c|c|}
\hline \multirow{2}{*}{$\begin{array}{l}\text { Sr. } \\
\text { No. }\end{array}$} & \multirow{2}{*}{ statements } & \multicolumn{3}{|c|}{ Male Students } & \multicolumn{3}{|c|}{ Female Students } \\
\hline & & Right & Wrong & NRNW & Right & Wrong & NRNW \\
\hline 1. & $\begin{array}{l}\text { Copying original software for } \\
\text { education purposes is: }\end{array}$ & 103 & 23 & 27 & 79 & 31 & 31 \\
\hline 4. & $\begin{array}{l}\text { Buying a paper online and } \\
\text { submitting it as your own is: }\end{array}$ & 57 & 61 & 35 & 40 & 61 & 40 \\
\hline 5. & $\begin{array}{l}\text { Copying and pasting an essay from } \\
\text { the Internet and submitting it as } \\
\text { your own is: }\end{array}$ & 59 & 61 & 33 & 37 & 63 & 41 \\
\hline 8. & $\begin{array}{l}\text { Listing web sites that you do not use } \\
\text { to complete a research paper in the } \\
\text { bibliography is: }\end{array}$ & 43 & 78 & 32 & 37 & 63 & 41 \\
\hline 9. & $\begin{array}{l}\text { Copying two lines from a printed } \\
\text { source, in your research work, } \\
\text { without acknowledging the source } \\
\text { is: }\end{array}$ & 30 & 89 & 34 & 27 & 78 & 36 \\
\hline 14. & $\begin{array}{l}\text { Unauthorized sharing of original } \\
\text { software with friends is: }\end{array}$ & 72 & 35 & 46 & 63 & 36 & 42 \\
\hline 15. & $\begin{array}{l}\text { Unauthorized sharing of music and } \\
\text { movies files with friends is: }\end{array}$ & 53 & 57 & 43 & 26 & 66 & 49 \\
\hline
\end{tabular}

Regarding the awareness about the ethical use of computer and IT resources of sampled teachers from public and private universities; it was found that teachers from private sector universities were more clearer in their believes than to the public sector university teachers. On the other hand, no significant differences found between the responses of sampled students either from public or private sector universities.

No significant differences found from the responses of male and female teaches either from public sector and private sector universities regarding the ethical utilization of computer and IT resources. Similarly, no drastic differences found from the responses of male and female students either from public and private universities. This helped to conclude that their ethical believes regarding the utilizations of computer and IT resources were same.

Regarding the activities (i.e., reflecting the ethical or unethical utilization of computer and IT resources) given in sixteen different statements in Part - II of the questionnaire, it was concluded that sampled teachers believed that: knowledge about ethical use of computer and IT, downloading diagrams or illustrations with complete references, unauthorized sharing of original software among friends and summarizing an article with the help of abstracts only for citation is ethically RIGHT. Copying original software for educational purposes, buying and submitting an online paper with their name, listing irrelevant websites in the reference list, downloading on online research tool for your own research work by ignoring the copy right acts and copying text either from online text or from printed content are ethically WRONG activities. Downloading music or movies from NET and explain a topic during lecture or demonstration without quoting each author are ethically Neither Right Nor Wrong (NRNW).

In case of students: majority of the sampled students copying original software for educational purposes, downloading music or movies, information regarding ethical use of IT, economically cheap access of IT based resources are the reasons of immorality, and unauthorized sharing of original software among friends is ethically RIGHT. Buying a paper online and submitting it as their own, copying and pasting text either from online resources or printed resources, explain a topic without quoting the real authors is ethically WRONG. And downloading on online research tool for your own research work by ignoring the copy right acts, listing irrelevant websites in references list and sharing of unauthorized sharing music and movies is ethically Neither Right Nor Wrong (NRNW) activities.

After conducting this study, it was strongly recommended to include Computer and IT ethics in all the course outlines in which computer and other IT resources are directly involved for providing proper knowledge. Moreover, conduct seminars, debates, discussions and conferences at all levels of education 
for not only highlighting the importance of computer and IT ethics but also broaden the awareness about the same. Sample size and targeted population of this research was limited. Therefore, it is also recommended to include more universities from different regions and provinces of the country to explore teachers and students understanding regarding the ethical use of computer and IT.

\section{REFERENCES}

[1] Alexandra, A., \& Miller, S. (2010). Law, Ethics and Governance Series: Integrity Systems for Occupations. England: Asgate. PP: 61, and 113.

[2] Baruchson-Arbib, S., and Yaari, E. (2004). Printed Versus Internet Plagiarism: A Study of Students' Perception. International Journal of Information Ethics, 1(6). Retrieved from http://container.zkm.de/ijie/ijie/no001/ijie 00105 baruchson.pdf

[3] Ben-Jacob, M. G. (2005). Integrating Computer Ethics across the Curriculum: A Case Study. Educational Technology \& Society, 8(4), 198 - 204.

[4] Benn, P. (1998). Ethics. London: UCL Press. PP: 1-5.

[5] Brey, P. (2007). Computer Ethics in (Higher) Education. Retrieved from http://www.utwente.nl/gw/wijsb/organization/bre $\mathrm{y} /$ Publicaties Brey/Brey 2007 HigherEducation.pdf

[6] Bynum, T. W. (2008). Computer and Information Ethics. Retrieved on December 12, 2011 from http://stanford.library.usyd.edu.au/entries/ethicscomputer/

[7] David, N. (2009). The impact of ICT in rural education: case study - ENUGU State. Nigerian Journal of Technology (NIJOTECH), 28(2), 70 - 79.

[8] Etter S., Cramer J. J., and Finn, S. S. (2006). Origins of academic dishonesty: Ethical orientations and personality factors associated with attitudes about cheating with information technology. Journal of Research on Technology in Education, 39(2), 133 155.

[9] Gliem, J. A., and Gliem, R. R. (2003). Calculating, Interpreting and Reporting Cronbach's Alpha Reliability Coefficient for Likert Type Scales. Retrieved from https://scholarworks.iupui.edu/bitstream/handle/1 805/344/Gliem\%20\&\%20..?sequence $=1$

[10] Goessl, L. (2008). How Computer Ethics Impact Society. Retrieved from http://www.helium.com/items/845336-howcomputer-ethics-impact-society

[11] Heersmink, R., Hoven, J., Eck, N. J., Berg, J. (2011). Biometric mapping of computer and information ethics. DOI: 10.1007/s10676-011-9273-7.
[12] Iskandarani, M., El-Refae, G., El-Etter, S. F. (2006). A rubber band ethics model for computing and information technology practices. American Journal of Applied Sciences, 3(7), 1910 - 1915.

[13] Irons, A. (2007). Teaching Computer Ethics to Computer Forensics Students. Retrieved from http://www.ics.heacademy.ac.uk/events/8thannual-conf/Papers/Alastair\%20Irons.pdf

[14] Jaggar, S. \& Strain, J. (2007). Assessing students' ethical development in computing with the defining issues test: Challenges to be addressed. Journal of Information, Communication and Ethics in Society. 5(1), $33-42$.

[15] Jamil, M. and Shah, J. H. (2011). Technology: Its potential effects on teaching in higher education. Journal of New Horizons in Education, 59(1), 38 51.

[16] Kizza, J. M. (2003). Ethical and Social Issues in the Information Age (2 ${ }^{\text {nd }}$ Edition). New York: Springer. PP: $38-48$.

[17] Kuzu, A. (2009). Problems Related to Computer Ethics: Origins of the Problems and Suggested Solutions. The Turkish Journal of Educational Technology - TOJET. ISSN: 1303-6521, 8(2), Article 9.

[18] Lee, W. W. \& Chan, K. C. C. (2008). Computer Ethics: A Potent Weapon for Information Security Management. Retrieved from http://www.isaca.org/Journal/PastIssues/2008/Volume-6/Documents/ipdf0806computer-ethics.pdf

[19] Lorents, A. C., Maris, J. M., Morgan, J. N. and Neal, G. L. (2006). Ethics of Computer Use: A Survey of Student Attitudes. Retrieved from http://www.franke.nau.edu/Faculty/Intellectual/wo rkingpapers/pdf/Morgan Ethics.pdf

[20] Masrom, M., Ismail, Z. and Hussein, R. (2009). Ethical Awareness of Computer Use Among Undergraduate Students. ACM SIGCAS Computers and Society, 39(1), 27 - 40.

[21] Masrom, M., Ismail, Z., Hussein, R., \& Mohamed, N. (2010). An Ethical Assessment of Computer Ethics using Scenario Approach. International Journal of Electronic Commerce Studies. 1 (1), 25 - 36.

[22] McCarthy, R. V., Halawi, L., \& Aronson, J. E. (2005). Information Technology Ethics: A Research Framework. Issues in Information Systems, VI (2). Pages: $64-69$.

[23] Obanor, A. I. and Kawasi-Effah, C. C. (2013). Assessment of university-industry collaboration and technology transfer in schools of engineering and sciences in Nigeria. Nigerian Journal of Technology (NIJOTECH), 32(2), 286- 293.

[24] Rigopoulos, G. and Karadimas, N. V. (2006). Increasing ethical awareness of IT students through 
online learning. Proceedings of the $6^{\text {th }}$ WSEAS International Conference on Applied Informatics and Communications, Elounda, Greece, August 18 - 20. 265-269.

[25] Rolstad, C. (2003). A Course in Computer Ethics for Engineering Students. Proceeding of International Conference on Engineering Education, Valencia, Spain. Retrieved from http://www.ineer.org/events/icee2003/proceeding s/pdf/3583.pdf

[26] Siegfried, R. M. (2004). Student attitudes on software piracy and related issues of computer ethics. Retrieved from http://home.adelphi.edu/ siegfried/ETIN2004.pdf

[27] Siegfried, R. M., Ashley, A. S. (2006). Is it theft or sampling? Student attitudes on the copying of commercial software and music. Retrieved from
http://www.academia.edu/2807904/Is it theft or s ampling Student attitudes on the copying of comm ercial_software and music

[28] Swain, C., and Gilmore, E. (2001). Repacking for the 21 $1^{\text {st }}$ Century: Teaching Copyright and Computer Ethics in Teacher Education Courses. Contemporary Issues in Technology and Teacher Education, (online), 1 (4), 535 - 545.

[29] Teston, G. (2008). Software Piracy among Technology Education Students: Investigating Property Rights in a Culture of Innovation. Journal of Technology Education, 20 (1), pp: 66 - 78.

[30] Young, K. S. (2009). Computer Ethics: Gender Effects and Employee Internet Misuse. Issues in Information Systems, X(2), 598 - 603. 